\title{
Rosmini: Thomist or Neo-Thomist? The Debate Continues
}

\author{
Nico P. Swartz \\ Faculty of Law \\ Dept. Roman Law, UFS, PO Box 339, Bloemfontein 9300. \\ E- mail: swartznp.rd@ufs.ac.za
}

\begin{abstract}
Neo-Thomism alludes to the aspect of renewal within the context of continuity. Thomas Aquinas himself effectuated expansion and renewal of the works of Aristotle. By virtue of this the neo-Thomist may not allow his thinking to become staid and stagnant in respect of the views of Thomas Aquinas. He should progress and make adjustments in keeping with the dynamics of the current period of time and should not merely relate the words of Thomas Aquinas. The neo-Thomist should carry into effect the spiritual thinking of Aquinas and where possible expound on this. On this basis neo-Thomism is indicative of expansion, renewal, originality and application. According to this premise Rosmini may be considered a neo-Thomist. On the question, whether he will also be considered a Thomist, the answer can be found in the opinions of Rosmini's advocates and opponents. Rosmini's advocate's, on the one hand, argue that he attempted to introduce innovative thinking to the Thomistic tradition that emphasized him as a neo-Thomist. His opponents, on the other hand, uphold traditional Thomism and were adamant that Rosmini could not be classified in terms of this grouping. This paper underpins a via media by emphasizing, on the one hand, that Rosmini's views of theology and philosophy fall within the ambit of traditional or classical Thomism. His theological and philosophical views would eventually replace Thomism as the official philosophy of the Catholic Church. According to Rosmini's advocates, his ideas were interpreted out of context by his opponents. They believe that Rosmini upheld traditional Thomism and that hostile political influences should be left out of the picture. It is evident in this paper that Rosmini's viewpoints uphold the fundamental truths of traditional Thomism while expanding on it in the light of the prevailing social and political context of the era. He applied the points of departure of Thomism in such a way that they gained a new and dynamic actuality. In this respect Rosmini's views fall into the category of neo-Thomism, in addition to the traditional or classical Thomism.
\end{abstract}

Keywords: Neo-Thomism, Thomist, Expanding, Advocates, Opponents, Influences, Renewal, Progress, Adjustments.

\section{Rosmini within the context of Thomistic thought}

\subsection{Towards a philosophical definition of Thomism}

In his definition of Thomism, J.D. Van der Vyver points out that both Thomism and neo-Thomism are indicative of the connection of Roman Catholic philosophy to the system of thought of Thomas of Aquino. (Note1) Robbers in turn shows that, apart from its connection to the thinking of Thomas Aquinas, neo-Thomism alludes to the aspect of renewal within the context of continuity: "Dit neo-Thomisme wil een Thomisme zijn dat St. Thomas zelf had leurinen voortbrengen in de 20 eeuen, met die sheuten die en by hem reeds waren 'n de 13de eeuw, krachtens een intense dynamiek, die ook het geestesleven van den mens en van die mensheid doet groeien." (Note 2)

Before recognising neo-Thomism legitimately as a form of Thomism, there should be clarity as to the actual meaning of Thomism. Up to now Thomism has been seen as an Aristotelian notion. However, owing to the originality of the theoretical view of Thomas Aquinas, Thomism is no longer associated only with Aristotelianism. Robbers accordingly argues that Thomism should also be determined on the basis of the views of Thomas Aquinas and not those of Aristoteles. Manser, on the other hand, claims that Thomism is indicative of the Aristotelian doctrine of the delimitation of faith and knowledge and the harmony that exists between the two. He states that the doctrine of actus and potentia of Aristoteles influenced Thomas Aquinas to such an extent that the latter also attempted to reconcile faith with knowledge. This particular Aristotelian teaching assumed a central position in the philosophical dogma and methodological moments of Thomas Aquinas. (Note 3) According to Robbers, Manser argues that Thomism can be detected in the following quotation which illustrates the development of the Aristotelian doctrines of actus and potentia: "[...] het scherp logisch en consequent doorvoeren en het verder voeren der aristotelische leer van potentia en actus." (Note 4) It was through this development that Thomas Aquinas earned himself the characteristic of originality. Manser writes that 
Thomas Aquinas further expanded and applied the Aristotelian doctrines of actus and potentia in a consistent and logical manner. (Note 5) In the official document, the Aeterni Patris of 1879, Pope Leo XIII emphasised the advancement and development of knowledge. His message was that the Aeterni Patris document should not be seen as the culmination of ideas, but rather as a point from which progress should continue to be made through further development and application. (Note 6) Pope Pius XI supported Leo XIII in his view that Thomism should not deviate from this developmental line of thinking of renewal and adjustment. They thus endorsed the expansion and intellectual development of traditional Thomism. Rosmini desired to be part thereof by assuming an active role as a contemporary thinker. It should be kept in mind that Thomas Aquinas himself effectuated the expansion, amendment and renewal of the works of Aristoteles. Rosmini has done the same with regard to the works and doctrines of Thomas Aquinas.

\subsection{Requirements for a Thomist to be considered a neo-Thomist}

Neo-Thomism comprises two significant moments: one embodies the thinking of Thomas Aquinas, and the other the thinking of the modern era. These are appropriately referred to as the conservative and progressive elements respectively. The neo-Thomist may be associated with the progressive element.

By virtue of his nature, the neo-Thomist may not allow his thinking to become staid and stagnant in respect of the views of Thomas Aquinas. Instead, the neo-Thomist should progress from the philosophical and theological opinions of Thomas Aquinas and make adjustments in keeping with the dynamics of the current period of time. This implies that where Thomas Aquinas may be silent on certain issues, further development and growth should be evident in the thinking of others in order to generate solutions to present-day problems. The neo-Thomist should thus be capable of original thinking which should further evolve in his works. He should not merely relate the words of Thomas Aquinas, but should carry into effect the spiritual thinking of Aquinas and where possible further expound on this. The following maxim should be put into effect: veteres novis augere (the ancient should be enriched with the modern). (Note 7) On the basis hereof neo-Thomism is indicative of expansion, renewal, originality and application and thus resides under the progressive element: "Veeleer dient rechtvaardigheidshalve de gehele oriëntatie van het neo-Thomisme met het predicaat progressief te worden aangeduid; het denker gevoel als heel het historisch bestaan der mensheid verkeert nu eenmaal 'n een proses, waarin geen stilstand beslaat." (Note 8) According to the above premise, Rosmini may be placed within the category of the progressive element and may be considered a neo-Thomist.

Can Rosmini also be considered to be a Thomist? In order to qualify as a Thomist, Rosmini will need to have upheld traditional or classical Thomism. Was this the actual case? The answer can be found in the opinions of Rosmini's advocates and opponents.

\section{The life and work of Antonio Rosmini}

Antonio Rosmini was born in 1797 in Rovereto, an Italian village that had formed part of the Eastern Hungarian Empire at that time. The Rosmini family maintained an affluent lifestyle owing to their involvement in the silk manufacturing industry. (Note 9) Rosmini's father was Baron Pier Modesto Rosmini-Serbati, the member of a wealthy aristocratic family of long standing. His mother was Countess Giovanne dei Formenti who came from Riva, along the lake of Garda. His parents were persons of culture, generosity and piety who zealously advanced the interests of the church. They had four children: Margherita (who became a nun), Antonio, Guiseppe and Felice, the youngest who died at an early age. (Note 10)

Rosmini completed his tertiary education in theology at the University of Padua and was ordained as priest in 1821. Because of his unique writing ability and with the encouragement of his colleagues, he spent his time writing books of theology rather than fulfilling his obligations as priest. (Note 11) His publications made a considerable impression in ecclesiastical and philosophical circles. His esteem within the church rose to such an extent that Pius IX considered promoting him to the rank of cardinal. (Note 12)

\section{Rosmini's influence on his followers}

During his lifetime and even several years after his death, Rosmini remained a controversial figure in Italy. Notwithstanding his reputation in Italy, he was relatively unknown in Europe.

W.J. (pseudonym) expresses the opinion that the magnitude of Rosmini's work in his relatively short lifetime accords him a place amongst the big thinkers and entitles him to a partnership with a small group of intellectuals. W.J. consequently places Rosmini on the same level as Aristoteles, Aquinas, Leibneitz, Kant and Hegel. He believes that Rosmini's views are of particular importance and considers him to be an "intellectual wonder". (Note 13) He states as follows regarding Rosmini: “... because he is alive, and writes for readers taught by all their Lockian and Protestant education to treat the kind of thing that Rosmini represents... thoroughgoing, concatenated, and systematic ontologizing and theologizing by the conceptions of principle and term, substance and essence and act..." (Note 14)

The writer, Thomas Davidson, highly appraises Rosmini's work. He considers Rosmini to be the most important philosopher of the nineteenth century and likens him to ancient philosophers such as Plato and Aristoteles. (Note 15) 
According to Davidson, Rosmini's work deserves to receive greater exposure and study since it makes a unique contribution to theology, philosophy, fundamental rights and human society. (Note 16)

Davidson believes that Rosmini's work is also of relevance outside Thomistic circles, not only with regard to theology, philosophy and fundamental rights, but also in respect of other scientific disciplines. (Note 17) He states that Rosmini's intellectual work provides clear parallels and cultural tangents with Thomistic and non-Thomistic schools of thought. (Note 18)

\section{Proponents and opponents or critics of Rosmini}

This article examines the diverse interpretations given to Rosmini's viewpoints. Both the opinions of those who supported Rosmini and those who criticised him will be discussed. Rosmini's advocates argued that he attempted to introduce innovative thinking to the Thomistic tradition. They emphasised neo-Thomism and believed that Rosmini belonged to this category of philosophical thinking. However, Rosmini's opponents upheld traditional or classical Thomism and were adament that Rosmini could not be classified in terms of this grouping.

\subsection{Rosmini's proponents}

Whereas the doctrine of Thomas Aquinas absolutises human reasoning, Rosmini states in his writings that such a theory is both subjective and flawed. (Note 19) Similarly to Thomas Aquinas, the British empiricists and German Romantic school absolutised reasoning, ignoring the illumination of faith. (Note 20) Davidson is of the opinion that Rosmini obviates the dangers of the absolutisation of subjective human reasoning by concentrating instead on the "light of divine reason" which is objective. (Note 21)

The writer, Beales, is of the opinion that the distinction between the "light of reason" and the usage of reason as found in Rosmini's Nuovo Saggio sull' Origine delle Idee (New Essay on the Origin of Ideas), constitutes an important expansion of Thomism. (Note 22) He points out that Rosmini became unpopular in ecclesiastical circles because his writings tended at times to run contrary to the Thomistic tradition. (Note 23) Later, two of his most well-known works were placed under censorship. (Note 24) One of these censored pieces, Delle Cinque Piaghe della Santa Chiesa ("The Five Wounds of the Holy Church"), which deals with the relationship between the church and the state, serves as an example of Rosmini's criticism of Thomistic doctrine. (Note 25)

The latter work is of particular importance for contemporary society and presents solutions to theological and philosophical issues faced by the church and state today. (Note 26) Irrespective of the considerable value of Rosmini's works and their theological and philosophical truths, they were placed on the Index Librorum Prohibitorum (Index of Forbidden Books) at the insistence of the Jesuits who presumably upheld the classical Thomistic doctrine of the Catholic Church. (Note 27) As Aubrey states in respect of the Jesuits' animosity towards Rosmini: “... his works were placed on the Index at the instigation of the Jesuits, then apparently released, and have been a subject of controversy ever since as to their ecclesiastical standing..." (Note 28)

Rosmini's Jesuit critics used his divergence from ecclesiastical viewpoints to discredit his writings. (Note 29) Since the Jesuits were one of the oldest orders of the Catholic Church, and since, according to Pesch, they maintained the strictest adherence to traditional Thomism as the official doctrine of the church, they called for a review of Rosmini's theological, philosophical and legal works. Rosmini's criticis' modus operandi was the upholding of classical or traditional Thomism. (Note 30) Their desire was to see Rosmini's works placed back on the Index of Forbidden books after previously having been removed from this list. After Pius IX refused to accede to the demands of the Jesuits, Leo XIII, his successor, granted them their request. (Note 31) Pesch writes: “... but hardly had a new and more pliable Pope ascended the throne, when they applied to him for a remedy against Rosminianism, in the shape of a rehabilitation of Thomism, pure and simple, as the philosophy of the Church..." (Note 32) Leo now launched a desperate attempt to reappraise the works of Rosmini to be in keeping with traditional Thomism as evident in his encyclical, Aeterni Patris, in 1879. (Note 33)

Boelaars explains the propensity that Pius had for traditional Thomism as follows: “.... Paus Leo XIII verborg van de begin af zijn voorliefde voor de wijsbegeerte van den H. Thomas niet. Reeds enkele malen had hij er blijk van gegeven, toen den 4 Augustus 1879, als derde zijner encyclicken, de wereldbrief Aeterni Patris verscheen: De philosophia christiana ad mentem sancti Thomae Aquinatis Doctoris angelici in scholis catholicis instauranda; over het herstel van de christelijke wijbegeerte naar den geest van den engelachtigen leeraar, den H. Thomas van Aquino, in de katholieke intichtingen van onderwijs." (Note 34) Boelaars alleges that Leo XIII recommended in an encyclical of June 1880 with the title Dum Vitiatae that the doctrine of Thomas Aquinas was to be followed according to the exegesis of Cajetanus, Ferrariensis, Liberatore, Sanseverino and Zigliara, and that Rosmini's doctrine was to be avoided. (Note 35) Leo XIII's revision of Rosmini's works ended with the condemnation of forty propositions from Rosmini's posthumous works. (Note 36) The decree, Sacred Congregation of the Index, was ratified on 6 June 1849 by Leo XIII. The condemnations listed in the Sacred Congregation of the Index are usually given in one of the following formulae, namely prohibeatur, prohibeatur donec corrigatur aut expurgetur and dimittantur. (Note 37) 
Rosmini's works were later released from censorship through the last-mentioned formula, the dimittantur, by a ruling of Pius IX in 1854 and could not be placed under censorship again. (Note 38) The dimittantur exonerated Rosmini's works from heresy, but made it clear that his works were to be considered dangerous or detrimental to the interests of the church: "... merely by their liability to misinterpretation in consequence of peculiar expressions and the particular temper of the times." (Note 39) Following the exoneration of Rosmini's works by means of the dimittantur of Pius IX, Leo XIII was only able in his decree, Post Obitum of 1887, to pronounce that forty propositions contained in Rosmini's prohibited works, Delle Cinque Piaghe della Santa Chiesa ("The Five Wounds of the Church") and the Costituzione Secondo la Giustizia Sociale ("Constitution on Social Justice"), were not in agreement with Catholic truths: "catholicae veritati haud consonae videbantur." (Note 40)

Reaction against the encyclical, Aeterni Patris, came from various quarters. The most impressive argument against the Aeterni Patris was that the pope was endeavouring to return civilisation to the Middle Ages. Boelaars considers the speech of Leo XIII of 7 March 1880, Pergratus nobis, to reflect this line of thought. Speculation followed Leo XIII's statements of the time and it was alleged that his preference for the Middle Ages led to the deduction being made that he wished to elevate the non-Christian Aristoteles above Christian philosophers such as St Augustine and Thomas Aquinas. Notwithstanding the allegations levelled against Leo XIII, the latter expressively campaigned for the execution of Thomistic philosophical education. (Note 41)

After Leo XIII's fervent campaign for a Thomistic tradition in the church (at the request of the Jesuits), Rosmini's 40 propositions stood no chance of being accepted by mainstream Catholic thinkers. Neither were his propositions in a position to penetrate the rest of the world. Now that attitudes towards Rosmini have changed as a result of the dedicated work of a few persons who believed in Rosmini's "system of truth" at the time of his vilification or persecution, it is the hope of this research that Rosmini's works will receive the general acceptance and credit that they deserve. (Note 42)

Sheldon believes that Giuseppe Morando made the assumption that Leo XIII was placed under pressure by the Jesuits and that this led him to subject the works of Rosmini to censorship - something which he would not otherwise have done. Sheldon is also of the opinion that Rosmini's propositions were in fact in keeping with healthy theological and philosophical teachings of the time and can be considered to be in accordance with Catholic standards. (Note 43)

Furthermore, Sheldon believes that as an adherent of Rosmini, Morando defended Rosmini's philosophical views. (Note 44) He remains convinced thereof that the rejection of Rosmini's philosophy was an injustice and expresses his dismay at the antagonistic references found in textbooks which discredit Rosmini's philosophy. According to Sheldon, Morando was thoroughly convinced that Rosmini was in no way guilty of disregarding the Catholic Church's doctrines. In this regard he refers to a quotation of Morando in which Pope Gregory XVI showed great regard for Rosmini: “... virum excellenti ac praestanti ingenio praeditum, egregiisque animi dotibus ornatum, rerum divinarum atque humanarum scientia summopere illustrem." (Note 45)

Sheldon believes that the rejection of Rosmini's teachings by the pontificate of Leo XIII was the consequence of improper influence on the part of the Jesuits and their political considerations. (Note 46) Some writers believe that Rosmini's teachings can be brought into relation with the viewpoints of Galileo. Sheldon explains that: “... over against an Inquisition which has committed the two greatest possible errors in the field of physical science and in that of metaphysics, in condemning Galileo and Rosmini, the rebels of today are the truest Catholics of tomorrow." (Note 47)

Sheldon also cites another advocate of Rosmini, Guiseppe Morando, who states that Rosmini's viewpoints are not at all contrary to Catholic opinions and that "... each of the forty condemned propositions can be justified as being in harmony with sound philosophy and theology, and agreeable to Catholic standards." (Note 48) In Morando's opinion Rosmini was not guilty of any serious divergence from church dogma.

The writer, Norman St John-Stevas, believed that Rosmini's theological and philosophical views would eventually replace Thomism as the official philosophy of the Catholic Church. (Note 49)

\subsection{Rosmini's opponents}

It is characteristic of Thomism to make a connection between theology and philosophy since these two fields supplement one another. (Note 50) In consideration hereof, Rosmini's views on theology and philosophy fall within the ambit of traditional or classical Thomism.

Rosmini believes that, although the soul possesses both a corporeal (natural) and a divine nature, it forms a unity that reaches maturity in humanity. (Note 51) Rosmini assumes that the good and divine nature of humankind will ultimately conquer the corporeal (natural) and that in this way mankind obtains participation in God, the Highest Being. This participation in the Godly, however, demands strict adherence to natural law. This view shows some parallel interpretations with the Thomistic analogia entis and participation theory. (Note 52)

The debate as to whether Rosmini's view of God or his theological viewpoints lead to pantheism, is a salient issue in view of the investigation to determine whether Rosmini's school of thinking belongs to neo-Thomism rather than 
traditional (classical) Thomism. Keeping this in mind, particular attention has been paid to specific doctrines of Rosmini. Proposition 20 of Rosmini's doctrines states that the human soul multiplies through generation: “... non repugnat ut anima humana generatione multiplicetur." (Note 53) This apparently deviates from the Thomistic viewpoint contained in the Summa contra gentiles which reads as follows: "... quod anima humana non traducatur cum semine." (Note 54) It should be kept in mind that Rosmini attempts in his doctrine to indicate that the human soul through development becomes one/unites with the esse initiale in the course of time. On the grounds hereof, Rosmini's viewpoint (Proposition 20) deviates from the Aristotelian-Thomistic doctrine in so far as the soul is concerned. (Note 55)

As already mentioned, Rosmini alleges in Proposition 22 that two soul constituents are present in the human body - one corporeal (natural) and the other divine (intellectual). (Note 56) In the human body these two soul constituents are joined together to form a unity so that the human body ultimately only has one soul. Winterton shows by means of a quotation from the works of Rosmini that the latter was an advocate of the idea that the two distinguishable soul constituents unite in the human body: “... God might possibly separate the intellectual principle from the animated body, without the latter ceasing to be animate: but if animate, there must remain some sort of anima or other. Was it there before, or not? If not, where does it come from now? If so, then there were two souls in man, existing together." (Note 57)

The Aristotelian-Thomistic theological viewpoint on the soul differs from that of Rosmini in so far as it advocates three soul constituents as opposed to Rosmini's two. Both Rosminianism and Thomism thus adopt the point of view that the human being possesses more than one soul constituent, the main difference between the two views being that Thomism under the influence of Aristoteles and Plato distinguishes three parts of the soul. The latter forms part of the theory of hylomorphism which means that an earlier form of the soul will be replaced by a later more developed form of the soul since "... generation requires corruption." (Note 58) Thomas Aquinas alleges that: “... when a more perfect form comes on, the prior is corrupted, but in such a way that the following form has whatever the first had, and still more." (Note 59) This in effect means that the vegetative soul constituent degenerates and is replaced by a more developed soul constituent, the sensitive soul part, which in turn further degenerates/becomes corrupt and is subsequently replaced by a rational soul constituent. (Note 60)

Rosmini argues that ultimately there is only one soul that remains in the human being, namely the rational soul constituent. He does not support the hylomorphistic view of Aristoteles and Thomas Aquinas and maintains that two soul constituents interact with each other in the human being rather than undergo a process of replacement whereby one soul constituent degenerates and is replaced by another. Rosmini believes that two soul constituents exist simultaneously. Hylomorphism, on the other hand, assumes a process of generation and constant degeneration/corruption. (Note 61)

According to Winterton, Rosmini's theological view on the soul is incorrect and the Thomistic view should be upheld as the valid one since it carries the support of the ecclesiastical magisterium. He supports his argument by stating that Rosmini in his Proposition 24 adopts the assumption that the soul does not constitute the substantial form of the body, but instead is the cause thereof. Winterton considers this statement to be contrary to Thomism with regard to the Aristotelian-Thomistic doctrine of form/matter whereby humanity is typified as the form of the soul. (Note 62)

Winterton later recuses his opinion on Rosmini and instead argues that Rosmini's ideas were interpreted out of context. He believes that it was as a result of political considerations that Rosmini was done an injustice and that he would never have published the propositions as it later became apparent. (Note 63) Hereby Winterton confirms that Rosmini upheld traditional Thomism and that hostile political influences should be left out of the picture.

According to Thomas Guarino, when John Paul II juxtaposed Rosmini's theology and philosophy with that of neo-Thomists such as Gilson and Maritain on the one hand, and with that of orthodox philosophers such as Florensky and Lossky on the other hand, this created a dilemma for some of the clergy. Although John Paul II wished to reconcile Rosmini with Thomism, Guarino states that Leo XIII in his encyclical, Aeterni Patris, expressed the opinion that Rosmini's theological views were divergent from those of Thomism. (Note 64) Leo XIII (supported by Ratzinger), according to Guarino, made the following statement: “... the adoption of Thomism created the premises for a negative judgement of a philosophical and speculative position like that of Rosmini because it differed in its language and conceptual framework from the philosophical and theological elaboration of St. Thomas Aquinas." (Note 65)

Guarino believes that owing to the divergent or heterodox interpretations accorded to Rosmini's work, Ratzinger came to view some of Rosmini's viewpoints as ambiguous and confusing. According to Guarino, Ratzinger considered Rosmini's theological views to be insufficient and inadequate and not in keeping with traditional (classical) Thomism. (Note 66) Notwithstanding Ratzinger's rejection of Rosmini's theological views, John Paul II declared in his encyclical, Fides et ratio, that Rosmini was one of the most recent writers to establish a fruitful relationship between theology and philosophy. With these words John Paul II implied that Rosmini's views were in no respect contradictory to traditional (classical) Thomism and that his theological and philosophical systems should rather be seen as a means of further 
developing classical Thomism. Rosmini's theological system accordingly affords Thomism with new opportunities to overcome challenges presented by modern-day thinking. John Paul II in effect provides scope in his Fides et ratio for the reinstatement of Rosmini's theological views. According to Guarino and Winterton this is unnecessary because Rosmini's posthumous works have not been interpreted in context. They argue that Rosmini was an adherent of traditional or classical Thomism. (Note 67)

\section{Conclusion}

In his encyclical, Aeterni Patris, Leo XIII upheld Thomism as the official point of view of the Catholic Church. Davidson states that Rosmini continued the Thomistic tradition in the nineteenth century, while relating the traditional and classical form thereof to modern tendencies. According to Davidson, however, Thomism was not always exempt from criticism. (Note 68) This explains why Rosmini's theological views received considerable attention, placing him on an equal footing with Thomism. In the event of a difference of opinion between the views of Thomas Aquinas and Rosmini, the latter's views should be accepted as the correct ones in the opinion of Davidson, because Thomism did not advocate a fixed theory. (Note 69) Davidson states as follows: “... they speak as if St. Thomas had settled all his views, before he began to write. Consequently, when they find contradictions in his writings (and these are not rare), they try, by what they call a 'benign interpretation,' to explain them away. Unfortunately, a benign interpretation generally means a disingenuous interpretation, and how far such interpretations may be carried may be seen in a little work by Father Cornoldi on St. Thomas's views with regard to the Immaculate Conception, in which that zealous Jesuit tries to show that St. Thomas meant exactly the opposite of what he said. The Saint's views on the Immaculate Conception were anything but orthodox. It is but fair to say that Cardinal Zigliara, in the volume before us, shows no tendency to benign interpretations, and that he treats his opponents, when speaking of them individually, with becoming respect..." (Note 70)

In summary, Rosmini's views differ in some respects from those of Thomas Aquinas. As already mentioned, Thomism has its shortcomings. Rather than acting in an offensive way towards Thomism, Rosmini makes an important contribution towards the further development thereof.

It can be seen from Rosmini's theological viewpoints that he endeavoured to uphold the fundamental truths of traditional (classical) Thomism while expanding on it in the light of the prevailing social and political contexts of the era. He applied the points of departure of Thomism in such a way that they gained a new and dynamic actuality. In this respect Rosmini's views also fall into the category of neo-Thomism, in addition to the traditional or classical Thomism.

In consideration of the above, it may be understood that the false dilemmas postulated by Rosmini's critics or opponents with regard to his position within Thomism, are of lesser importance for the time being.

\section{References}

Andreotti, G. 2007. 30 Giorni nella Chiesa e nel mondo. (30 Days in the Church and in the World). Year xxv, no. 9.

Aubrey, E. 1934. Review. Scriti autobiografici inediti. (Collected by Enrico Castelli). Rome: Anonima Romana Editoriale. The Journal of Religion, vol. 15, no. 3: 369.

Beales, A.C.F. 1957. Review. Rosmini: Priest, Philosopher and Patriot. By Claude Leetham. London: Longman. British Journal of Educational Studies, vol. 6, no. 1: 91.

Blau, J.L. 1955. Review. Rosmini, Domodossola, and Thomas Davidson. Journal of the History of Ideas, vol. 18, no. 4, 1957: 522-525.

Boelaars, H. 1948. z.h. Paus Leo XIII van 4 Augustus 1879 over: Het Herstel van de Christelijke Wijsbegeerte naar den Geest van den H. Thomas van Aquino. Tweede druk. N.V. Gooi \& Sticht - Hilversum.

Burke, R. 1977. Review. Catholic Theology in the Nineteenth Century: The Quest for a Unitary Method by Gerald A. McCool. New York: The Seabury Press. Journal of the American Academy of Religion, vol. 46, no. 4, 1978: 600-601.

Burns-Gibson, J. 1882. Review. The Philosophical System of Antonio Rosmini-Serbati. Translated with a sketch of the author's life, bibliography, introduction and notes by Thomas Davidson. London: Kegan Paul. Mind, vol. 7, no. 27: 389-409.

Davidson, T. 1882. The Philosophical System of Antonio Rosmini-Serbati. Translated with a sketch of the author's life, bibliography, introduction, and notes. London: Kegan Paul, Trench \& Co., 1, Paternoster Square.

Davidson, T. 1883. Review. Sancti Thomae Aquinatis, Doctoris Angelici. Opera Omnia. Mind, vol. 8, no. 32: 610-616. Encyclopaedia Britannica. 1768. Vol. 19. London: William Benton Publishers.

Guarino, T. 2003. Review. Rosmini, Ratzinger and Kuhn. Observation on a note by the Doctrinal Congregation. Theological Studies, vol. 64: 43-68.

http://www.jstor.org/view 
http://mb-soft.com/believe/txoneothomi.htm

John-Stevas, N. St. 1953. Philosophy of law. By Giorgio Del Vecchio. Translated from the 8th edition by Thomas Owen Martin. Washington: The Catholic University of America Press. The Modern Law Review, vol. 18, no. 1, 1955: 82-84.

Leetham, C. 1982. Rosmini. Priest and Philosopher. With an introduction by Giuseppe Bozzetti. New York: New City Press.

Pasnau, R. 2002. Aquinas on Human Nature. Cambridge University Press: United Kingdom.

Pesch S.J., T. 1880. Review. Institutiones Philosophiae Naturalis secundum Principia S. Thomae Aquinatus ad usum Scholasticum accomodavit. Critical notices. Friburgi Brisgoviae: Herder Press. Mind: 424-427.

Rickaby, J. 1950. Of God and His Creatures. Maryland, Westminster: The Carrol Press.

Robbers, H. 1951. Neo-Thomisme en die moderne wijsbegeerte. Brussel.

Rosmini, A. 1861. Church Reformation in Italy. Torino.

Rosmini, A. 1882. The Philosophical System of Antonio Rosmini-Serbati. London: Kegan Paul, Trench \& Co., 1 Paternoster Square.

Rosmini, A. 1987. The Five Wounds of the Church. Translated by Denis Cleary. Fowler Wright Books: Leominster. Rosmini House, Durham: England.

Rosmini, A. 1992. Introduction to his Life and Teaching. Rosmini House, Durham: England.

Rosmini, A. 2001. A New Essay concerning the Origin of Ideas. Bell \& Bain Limited, Glasgow: England.

Rosmini, A. 2004. Introduction to Philosophy. About the Author's Studies. Bell \& Bain Limited, Glasgow: England.

Schlumpe, H. \& Schorn, J. 2001. Review. Rome rehabilitates Rosmini. United States Catholic: 11.

Sheldon, H.C. 1905. Review. Rosmini interpreted and defended. The American Journal of Theology, vol. 9, no. 3: 538-585.

Van der Vyver, J.D. 1974. Hedendaagse Calvinistiese en Rooms-Katolieke natuurregsteorieë. Tydskrif vir Hedendaagse Romeins-Hollandse Reg. Band xxxviii, no. 1: 380.

Van der Vyver, J.D. 1975. Hedendaagse Calvinistiese en Rooms-Katolieke natuurregsteorieë. Tydskrif vir Hedendaagse Romeins-Hollandse Reg. Band xxxviii, no. 1: 66.

Winterton, F. 1888. Review. Papal condemnation of Rosmini. Notes. Mind, vol. 13, no. 52: 622-626.

W.J. 1885. Review. Rosmini’s Psychology. Vol. 11. London: Kegan Paul, Trench \& Co. Science, vol. 8, no. 183, 1886: 130.

\section{Notes}

Note 1. Van der Vyver 1974: 66.

Note 2. Robbers 1951: 83.

Note 3. Robbers 1951: 56.

Note 4. Robbers 1951: 56.

Note 5. Robbers 1951: 50.

Note 6. Robbers 1951: 79.

Note 7. Robbers 1951: 53.

Note 8. Davidson 1882: xxvii-xxviii.

Note 9. Davidson 1882: xxvii.

Note 10. Leetham 1982: 125. Cardinal Morozzo warned Rosmini not to devote his attention to other matters, but to reflect on the words of Pius VIII spoken to him. The Vicar General, Monseigneur Scavini, cited the words of Pius VIII to Rosmini as follows: "... that he should not undertake that part of the ministry, but that he should attend to the more important work of study and writing books for the benefit of religion and good morals."

Note 11. Rosmini 1861: 125. The plans of Pius IX were obstructed by his self-imposed exile to Gaeta. Pius IX would later be influenced by other unfavourable circumstances to launch an investigation into Rosmini's works. Hereby Rosmini's promotion to the Cardinalate was suspended.

Note 12. Giulio Andreotti 2007: 35. 
Note 13. W.J. (pseudonym) 1885: 130.

Note 14. See W.J. 1885: 130.

Note 15. See Blau 1955: 525.

Note 16. One such work of Rosmini bears the title Sistema Filosofico (The Philosophical System of Rosmini). In this piece Rosmini discusses theology, philosophy, rights and human rights and their respective social contexts.

Note 17. Davidson 1883: 616.

Note 18. Davidson 1883: 614.

Note 19. Rosmini 2001: xii. Rosmini believes that human reasoning is prone to error because it is an act of the will rather than the product of the intellect.

Note 20. Davidson 1882: 400-404. Davidson explains that Rosmini considers the Kantian form of human reasoning as subjective since it is material/substantive and not formalistic, a posteriori and not a priori. Through his principle of the objectivity of the first principle, Rosmini formulated a twofold system to ward off the criticism of Hegel, Fichte and the English school of thought. This system deals respectively with Rosmini's teaching of self-consciousness and his theory of perceptions. By means of this twofold system, Rosmini could determine that the being was the object of the intellect, the principle of observation - "that which is."

Note 21. Rosmini 2001: viii.

Note 22. See Beales 1957: 91. Beales believed that Rosmini's deep insight into the modern outlook of the nineteenth century enabled him to bridge the schism between the Christian tradition and contemporary thinking.

Note 23. Schlumpe et al. 2001: 11. David McClaurin alleges that owing to the publication of Rosmini's theological work, Delle Cinque Della Santa Chiesa, even years after his death Rosmini was held in contempt by Thomism and its adherents. Even to this day Rosmini is still subjected to humiliation. Schlumpe and Schorn cite Mc Claurin himself: “... (Rosmini's) posthumously published works were picked over..." and “... in what must surely be one of Church history's most shameless acts of character assassination..."

Note 24. Rosmini 1992: 14. The works placed on the Index were Delle Cinque Piaghe della Santa Chiesa (Of the Five Wounds of the Holy Church) and La Costituzione Civile Secondo la Giustizia Sociale (Constitution on Social Justice).

Rosmini 1882: xxxvi-xxxvii, xxxix.

Note 25. Rosmini 1987: 1-194. Rosmini mentions the state's interference in ecclesiastical affairs under the fourth wound of the church. He argues that the nomination of bishops should not lie in the hands of the civil authorities. The nomination of bishops remains the exclusive mandate of the church.

See Leetham 1982: 362-71.

Note 26. Rosmini 1861: 119-20.

Rosmini 1987: 67-132. Using allegory Rosmini analogises the five wounds of Christ as typical examples of how harm is being inflicted on the church. The five wounds of the church are regulated by Rosmini's Della Cinque Piaghe della Chiesa ("Of the Five Wounds of the Church"). The fourth wound specifically is indicative of the relationship between the church and the state and deals with the nominations of bishops by the state. Stately nominations of bishops culminate in the enslavement of the church to the state. The church is a free society and has the right to elect or nominate its own officials. Rosmini believes that when the state interferes in church matters the personal interests of the clergy are influenced to such an extent that they neglect their apostolic work: “... it was not possible that having become the king's men they should have it equally present to their minds to remain the men of God." The church then finds itself in alliances with state officials (princes) who negotiate for concessions that are detrimental to the church. Arising from the dissatisfactory condition or position of the church, Rosmini proposes the immediate and complete liberation of the church from any partnerships with the state.

Note 30. Leetham 1982: 368-370. Rosmini states that nominations of bishops were made from the fifth century after Christ "per clerum et populum". Up to and including the twelfth century, popes were able in terms of this formula to declare invalid the nominations of bishops who failed to meet the requirements of the formula. Thereafter, a system of papal reservation applied during the French pope's stay at Avignon. In the fifteenth century the nominations of bishops were removed from the clergy and placed in the hands of the See Encyclopaedia Britannica vol.19: 633.

http://web 3.epnet.com, 1.

See Britannica Biography Collection.

Note 27. See http://www.jstor.org/view, 2.

Note 28. See Aubrey 1934: 369. 
Note 29. Pesch 1880: 424, Davidson 1883: 144-7. Pesch believes that about a century ago when philosophy in Europe came under the attack of sensism, criticism and Hegelianism and the Jesuits were imposing a form of materialism on the church, Rosmini strove to restore dignity to reason and to elevate reason to the foundation of religion or theology. He did this by focusing on the traditional philosophy of the church - Thomism. Pesch states that Rosmini was successful in his attempt and that the Jesuits wished to bring him over to their side. When they ascertained that Rosmini employed an entirely different philosophical and theological system to theirs and that he would not allow himself to be used for their own profit, the Jesuits started to discredit Rosmini's works. After they failed to have Rosmini's works placed on the Index, the Jesuits attempted through private slander to create the impression that Rosmini's works contained erroneous doctrines and convinced the church to restore Thomism in a way that excluded Rosmini's proposed improvements to Thomism. During the pontificate of Pius IX the Jesuits were unsuccessful in their attempts to have Rosmini's works placed on the Index. Parkinson states that when Leo XIII, who was a more pliant pope, ascended the throne, the Jesuits advocated a remedy against Rosmini's works in the form of the rehabilitation of Thomism as the church's philosophy: "... and a distinct condemnation of its improved form (Rosminianism)." He feels that Leo XIII failed to restore Thomism: " $\ldots$ because his hands were tied by a decree of the Congregation of the Index which had declared Rosmini's words free from censure." Parkinson states that the Congregation of the Index never gave the decree "nihil censura dignum", but rather the "dimittantur." He believes that the "dimittantur" in no way served to give approval to Rosmini's works and that in his opinion a decree of the Congregation of the Index could be revoked by the pope. According to Parkinson, the pope's hands were not actually tied by the decree of the Congregation of the Index. He states that after the encyclical, Aeterni Patris, the Jesuits flooded the world with books in order to confirm the doctrines of Thomism as the official doctrines of the church (secundum principia S. Thomae Aquinatis). Parkinson explains that the Jesuits' views corresponded more with those of Rosmini than with those of Thomism: “... the Jesuits are... emphasizing views that are often quite as much at variance with those of St. Thomas as with those of Rosmini, against which they were directed."

Davidson 1882: 146.

Note 30. Burke 1977: 600. Burke is of the opinion in his book discussion of Mc Cool that the latter supported the maintenance of classical Thomism and states as follows: “... and Mc Cool points out, he was also crucial to the development of Thomism into a seedbed for pluralistic theology in the age of Vatican II." Burke's approach is contrary to the neo-Thomistic tradition. Rosmini shows a strong disapproval for the nineteenth century secular rationalism and instead shows a desire to uphold classical Thomism while at the same time enabling adjustment to new changing circumstances. Rosmini's ideas could thus serve as a bridge between classical Thomism and neo-Thomism.

Note 31. See Pesch 1880: 425.

H. Boelaars 1948: 12. Pope Leo declared in his encyclical, Dum vitiatae of 21 June 1880, that the doctrine of Rosmini should rather be avoided: "Dit werd in Italië zeer goed begrepen, want in meerdere adhaesiebetuigen van Italiaansche bisschoppen en seminarieprofessoren werd onder aanhaling van deze woorden de belofte gedaan de leer van den $\mathrm{H}$. Thomas te onderwijzen volgens den uitleg van Cajetanus, Ferrariensis, Liberatore, Sanseverino, Zigliara, en de leer van Rosmini te vermijden.”

Note 32. See Pesch 1880: 752.

Note 33. See Pesch 1880: 424-5.

Note 34. Boelaars 1948: 9.

Note 35. Boelaars 1948: 12.

http://mb-soft.com/believe/txoneothomi.htm, 1. In the early nineteenth century in Italy certain scholars in the Thomistic school considered the doctrines of Aquinas to be basic principles that could resolve the problems created by Kantianism, Hegelian idealism, British empiricism, rationalisation, skepticism and liberalism. During 1850 neo-Thomism and neo-Scholasticism were reflected in the works of Gaetano Sanseverino in Naples and Matteo Liberatore in Rome. The publication of Leo XIII's Aeterni Patris in 1879, which was known as the "charter of neo Thomism", took their endeavours to a new climax. By means of ensuing encyclicals, Leo XIII emphasised the application of Thomistic ideas as a means of affording solutions to contemporary problems. Successive popes, including John Paul II, stressed the importance of a Christian philosophy based on Thomistic principles.

Note 36. Boelaars 1948: 12.

Note 37. Rosmini 1861: 125. The first formula, prohibeatur, was used when a book was condemned as a result of heretical and immoral doctrines. The second formula implies that a book, although considered to be detrimental, was still capable of undergoing change. Such book should, however, not be offensive to the Catholic faith. The third formula is indicative of the acquittal or exoneration of a book.

Note 38. Encyclopaedia Britannica: 561. 
Note 39. Rosmini 1861: 126.

Note 40. Rosmini 1992: 69. Under the decree of Leo XIII, Post Obitum, forty of Romini's works from his lifetime and also from his posthumous works were censored. Under the suspicion that Rosmini's works were catholicae veritati haud consonae videbantur (hardly in agreement with Catholic truths), Rosmini's propositions were condemned as being reprobandae, damnandae and proscribendae (condemned, censored and banned). Notwithstanding these negative interpretations attached to Rosmini's works, his works were not considered to be heretical, offensive to the pious ear, or in any way damnable. Cleary believes that there were three reasons why Rosmini's works were condemned. Firstly, the charge against some of the propositions as being catholicae veritati haud consonae was theologically motivated rather than philosophically based. No other opinion or explanation can be given to the phrase "catholic truth". Secondly, the first 24 propositions concern philosophical issues; especially the question as to the intellectual relationship between humanity and God. It was the opinion of the Sacred Congregation of the Index that Rosmini's view on such a relationship should be undermined from the very outset. Thirdly, Rosmini's proposition cited from his Teosofia is a concentration of views taken from various writings that comprise several pages and more than one volume of the book. Rosmini's reference on this is clear: "Finite reality is not, but he (God) makes it be by adding limitation to infinite reality" (Teosofia, volume 1, no. 681); "Initial being... becomes the essence of every real being" (ibid., no. 458); "Being, which actuates finite natures, joined with these by being cut off from God..." (vol. 3, no. 1425).

Cleary alleges that the practical impossibility of giving meaning to these words without reference to their contexts is self-indicative of the difficulties encountered by the writers in their attempt to prove that Proposition 12 shows that Rosmini may be accused of pantheism. Cleary believes that Rosmini's actual viewpoint against pantheism is evident in his commentary on the Gospel of John: “... when there is questions of the modes in which the divine subsistence is limited, we do not mean that the divine substance receives, or can receive limitations. However, the divine substance is being, and consequently being which, as its concept shows, is able to be in two modes, unlimited and limited. Unlimited and unchangeable being is proper to the divine substance; limited being is proper to the creature. The divine substance contains therefore the possibility of creatures because in it is to be found being which can be limited. But the creature is not present in the divine substance. What is present - because being is present, and being contains in its concept the possibility of limitation - is the reason underlying the creature's possibility of existence. The possibility proper to creatures is, however, twofold; logical and physical. The logical possibility is the idea, or the reason underlying creaturehood; the physical possibility is the power, or efficient cause of the creature, that is, the creative power. Absolute being, therefore, contains in its concept both the idea of limited being, that is, of the creature, and the power to produce the creature, that is, to render real and subsisting the limited being manifest in the idea. In a word, the absolute being possesses all that is needed to make itself creator, creator of limited being, of the creature, by making the creature real and subsistent."

Rosmini 1861: 125-6.

Note 41. Boelaars 1948: 13.

Note 42. Rosmini 1992: 71.

Note 43. See Sheldon 1905: 583, 584. Sheldon believes that as a result of the injustice of rejecting Rosminian philosophy, Morando was prepared to challenge the authority of the church. He alludes to three allegations as to why the authority of the church could be challenged. Sheldon states first of all that there was division as to the rejection of Rosmini's works. While Gregory XVI expressed his praise for Rosmini's philosophical works, the Jesuits did everything in their power to have Rosmini's works placed under censorship. There also appeared to be a lack of consensus between Pius IX and Leo XIII on Rosmini's works. Sheldon believes that Pius IX was of the opinion that the two censored books of Rosmini, namely Delle cinque Piaghe della Santa Chiesa of 1848 ("Of the Five Wounds of the Church") and the La Costituzione secondo la Giustizia Sociale of 1848 ("Constitution of Social Justice"), in no way diminished the merits of the theological and philosophical system of Rosmini. According to Sheldon the censorship of Rosmini's works under the pontificate of Leo XIII was a case of: “... pope and congregation being at variance with pope and congregation..."

Secondly, Sheldon alleges that Morando's contempt of the church's authority was the result of mistakes made at the time of the Inquisition and the pope's support of these mistakes. He quotes Morando himself as referring to: “... over against an Inquisition which has committed the two greatest possible errors in the field of physical science and in that of metaphysics, in condemning Galileo and Rosmini, the rebels of today are the truest Catholics of tomorrow."

Sheldon believes that the third allegation levelled against the authority of the church and also the reason why Morando could not accept with resignation the censorship of Rosmini's works, was his assumption that Rosmini's works did not attack Catholic doctrines. Morando rejected the charge of pantheism used by Rosmini's critics against him and alleged that Rosmini had not deviated from Catholic dogma. 
Note 44. Sheldon 1905: 583. “... Professor Morando gives expression in the whole body of his work, namely, the conviction that the teaching of Rosmini offends against no genuine Catholic premise... he maintains, each of the forty condemned propositions can be justified as being in harmony with sound philosophy and theology, and agreeable to Catholic standards... Morando adequately refutes the charge of pantheism, which evidently was uppermost in the minds of the censors, and makes it plain that on most of the points embraced in the passages selected for reprobation Rosmini was not guilty of any serious divergence from Catholic dogma."

Note 45. See Sheldon 1905: 583. He considers Rosmini to be a person of exceptional quality blessed with an outstanding intellect and someone who was passionate and imbued with an extraordinary ability to relate divine matters to human science with much tolerance.

Note 46. See Sheldon 1905: 583-4.

Andriotti 2007: 35. Cardinals who were well disposed towards Austria, such as Giacomo Antonelli for example, opposed Rosmini.

Note 47. See Sheldon 1905: 584.

Note 48. See Sheldon 1905; 584.

Note 49. John-Stevas 1953: 83.

Note 50. Rosmini 2004: 36.

D’Entréves 1965: xiii. Thomism also maintains that the fields of theology and philosophy should fundamentally be in harmony with one another: "Gratia non tollit naturam sed perficit."

Note 51. Rosmini 1991 (a): viii-ix. Rosmini states: "The human being is 'an animal subject endowed with the intuition of indeterminate, ideal being and with the perception of its own corporeal, fundamental feeling, and operating in accordance with animality and intelligence... intellect and reason on the one hand, and will and freedom on the other, are respectively the active and passive faculties that constitute the human spirit."'

Note 52. Van der Vyver 1975: 66. The concept analogia entis is an outcome of attempts of Thomism to include God and His creation. The most general term adopted by Thomism is that of the being. The similarities between God and creation are analogous. The analogia entis thus points out that God and the world find a common foundation in the being, but in such a way that God and the world vary from each other. On the basis of the analogia entis humanity participates in the being of God and carries something divine (the transendentalia) within.

Note 53. The human soul does not multiply by means of generation.

Note 54. Because the human soul is not transposed through procreation.

Note 55. See Pasnau 2002: 110-111. The doctrine on hylomorphism states that the soul is only infused when the foetus has developed adequately. Rosmini's perception is that it is a long time after the soul first comes into being and only after its unification that it reaches incorporeality. The Aristotelian-Thomistic perception would appear to be the most correct conclusion. Rosmini does not provide an elaborate system for the perception of incorporeality.

Note 56. Winterton 1888: 625. “... two souls, one sensitive and the other intellectual..."

Cf. Rosmini 1991 (a): ix.

Note 57. Winterton 1888: 625.

Note 58. Pasnau 2002: 124.

Note 59. Pasnau 2002: 125

Summa Theologiae I, q. 118, a. 2 ad 2.

Note 60. Pasnau 2002: 122. “... the vegetative soul comes first, when the embryo lives the life of a plant. Then it is corrupted, and a more complete soul follows, at once both nutritive and sensory, and then the embryo lives the life of an animal. But once this is corrupted, the rational soul follows, introduced from without."

See Rickaby 1950: 169.

The discourse over the soul constitutes the basis of the ethics in Rosmini's study on the civil societas and is dealt with in the appropriate chapter.

Note 61. Pasnau 2002: 123 "Aquinas,... contends that generation involves constant, radical discontinuity."

Note 62. Winterton 1888: 626. Winterton alleges that the propositions contained in Rosmini's posthumous works would have undergone a completely different formulation had Rosmini still been alive.

Winterton 1888: 625. Rosmini alleges contrary to Catholic dogma that the soul does not constitute the substantial form of the body, but is rather the cause of that substantial form: "Forma substantialis corporis est potius effectus animae, 
atque interior terminus operationis ipsius: propterea forma substantialis corporis non est ipsa anima. Unio animae et corporis proprie consistit in immanenti perceptione, qua subjectum intuens ideam affirmat sensibile, postquam in hac ejus essentiam intuitum fuerit." (The substantial form of the body is rather the result/effect of the soul, but the internal activity of the soul is its own: therefore the substantial form of the body is not the soul itself. Unity of the body and soul is forged with great magnitude whereby the two are subjected to the same inner sensory perception and that unity is perceived as essentiality/materiality.)

Note 63. Rosmini had numerous enemies amongst the Jesuits. Their jealousy caused them to distort Rosmini's ideas after his death in order to bring him into opposition with Thomism.

Note 64. Guarino 2003: 46. Guarino is convinced that Leo XIII was influenced by the divergent or heterodox interpretations attached to Rosmini's posthumous works: “... an apparatus capable of defining the precise meaning of the expressions and concepts used... this favored a heterodox interpretation of Rosminian thought as did the objective difficulty of interpreting Rosmini's categories, especially when they were read in a neo-Thomistic perspective."

Note 65. Guarino 2003: 45.

Note 66. Guarino 2003: 46. Ratzinger states that “... the philosophical-theological system of Rosmini was considered insufficient and inadequate to safeguard and explain certain truths of Catholic doctrine."

Note 67. Guarino 2003: 56.

Winterton 1888: 626.

Note 68. Davidson 1882: 616.

Note 69. Davidson 1882: 616. With reference to the phrase: “... St. Thomas means exactly the opposite of what he said," it may be deduced that Thomism did not uphold a fixed theory.

Note 70. See Davidson 1883: 616.

The author wants to express his gratitude towards Prof H.A. Wessels. 